\title{
Advanced Hypopharyngeal Squamous Cell Carcinoma
}

National Cancer Institute

\section{Source}

National Cancer Institute. Advanced Hypopharyngeal Squamous Cell Carcinoma. NCI Thesaurus. Code C150210.

A squamous cell carcinoma of the hypopharynx that has spread extensively to other anatomical sites or is no longer responding to treatment. 